\title{
Determining a charge for the clearing of invasive alien plant species (IAPs) to augment water supply in South Africa
}

\author{
JN Blignaut ${ }^{1 *}$, C Marais ${ }^{2}$ and JK Turpie ${ }^{3}$ \\ ${ }^{1}$ Department of Economics, University of Pretoria, Pretoria 0002, South Africa \\ ${ }^{2}$ Executive Manager: Strategic Partnerships: Working-for-Water, Private Bag X4390, Cape Town 8000, South Africa \\ ${ }^{3}$ Percy Fitzpatrick Institute, University of Cape Town, Rondebosch 7701, South Africa
}

\begin{abstract}
South Africa is running out of water supply options. One option, however, is to control invasive alien plant species (IAPs) within water catchment areas and in riparian zones. The National Water Act and subsequent documentation provide a guide for the use of economic instruments to manage invasive alien plant species at a national, but also at a water management area level. This paper determines the method and level of such an invasive alien plant control charge as part of the water resource management charge.
\end{abstract}

Keywords: natural capital, invasive alien plants, water runoff, water pricing, water charges

\section{Introduction}

Natural resources are increasingly becoming the limiting factor to development as eloquently articulated by Daly, quoted by Aronson et al. (2006):

'More and more, the complementary factor in short supply (limiting factor) is remaining natural capital, not manmade capital as it used to be. For example, populations of fish, not fishing boats, limit fish catch worldwide. Economic logic says to invest in the limiting factor. That logic has not changed, but the identity of the limiting factor has.'

In South Africa, an arid developing country, water is indeed becoming the limiting factor to development (Scholes, 2001). The question therefore arises: given the supply constraints, what can be done to augment the water supply in the best possible manner? Historically, water resource managers met rising water demands through the establishment of a complex system of engineering supply-side solutions, but this is no longer viable due to the limited number of rivers that can still be exploited in this way and the rising marginal cost of this option (Smakhtin et al., 2001).

Government, as trustee and custodian of the nation's water resources (DWAF, 1998), is responsible for the protection, development and management of the resource in an equitable and sustainable manner for the benefit of all people. To be able to effect this objective, the National Water Act makes provision for the use of economic incentives for water management. The Act states that 'the Minister . . . may establish a pricing strategy for charges for any water use' (Clause 56) (DWAF, 1998). While increases in water tariffs are usually viewed as a market-based demand-side intervention, water tariffs could also be used to pay for the delivery of an environmental good and service (Pagiolo et al., 2002).

It has been indicated (Cullis et al., 2007; Görgens and Van Wilgen, 2004; Van Wilgen et al., 2001) that invasive alien plant species (IAPs) lead to an undesirable reduction of streamflow

* To whom all correspondence should be addressed.

喕 +27 84 720-4127; fax: +27 12 808-0905;

e-mail: james@jabenzi.co.za

Received 20 July 2006; accepted in revised form 31 October 2006. and water yield. A charge aimed at preventing and eventually controlling invasive alien plant species will therefore render both an ecosystem service (increased water flow to augment the Ecological Reserve) and water as utilisable resources. The specific question addressed in this paper is therefore: What should be the structure, size and distribution of a charge to eradicate IAPs over a 25 -year cycle? This question will be investigated by focusing on a water- augmentation scheme linked to the removal of IAPs in riverine and mountain catchment areas (watersheds), which are the areas in which IAPs have the most profound impact of water resources.

To investigate this problem, the study will first provide an overview on the relative scarcity of water in South Africa followed by a discussion on the impact of IAPs on streamflow reduction. Consideration will then be given to the size and distribution of a payment system required for the removal of IAPs from mountain catchment areas and riparian zones, followed by a discussion and some concluding remarks.

\section{Water in South Africa}

\section{Current situation and future prospects}

South Africa has an average precipitation of approximately $500 \mathrm{~mm} / \mathrm{a}$, well below the world average of about $860 \mathrm{~mm} / \mathrm{a}$ (DWAF, 2002). Rainfall has also become increasingly more erratic during the latter part of the previous century with 1998 and 1999 being the $4^{\text {th }}$ and $5^{\text {th }}$ wettest years recorded over the period 1921 - 1999. Additionally, both the frequency and intensity of the swings between dry and wet years are increasing. This implies that water resource and supply management is becoming more difficult, and hence more important. To make matters worse, South Africa is poorly endowed in groundwater because most of the country is underlain by hard rock formations that do not contain any major groundwater aquifers (DWAF, 2002). It is therefore not surprising that South Africa has been classified as a country with chronic water scarcity (Ashton, 2002).

The demand for water in South Africa is dominated by the agricultural sector (about 60\%), as indicated in (DWAF, 2004). 
Large-scale farmers primarily use $95 \%$ of irrigation water and small-scale farmers use the remainder (Schreiner and Van Koppen, 2002). Afforestation requires $4 \%$ of the total water requirement and rural and urban populations require $4 \%$ and $25 \%$, respectively. Mining and bulk industrial, and power generation use $6 \%$ and $2 \%$, respectively.

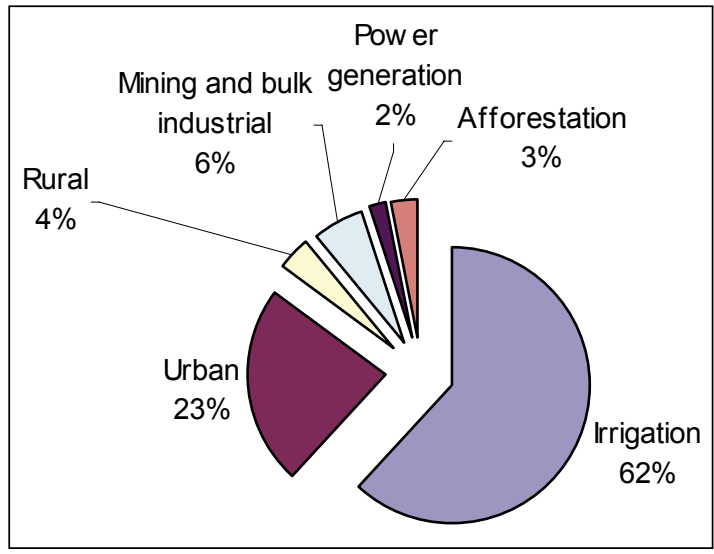

Figure 1

Water requirements by sector in South Africa: 2000 Source: DWAF (2004)
DWAF (2004) estimates that the current balance of unutilised water yield is approximately $186 \times 106 \mathrm{~m}^{3}$. This implies that South Africa's total surplus (or unutilised water yield) only $1.4 \%$ of the country's total water supply is. DWAF's baseline scenario for 2025 is that South Africa as a whole is likely to have a water deficit of approximately $1.7 \%$. The amount of surplus water available for utilisation of any kind is therefore declining fast and this emphasises the need to find innovate ways to augment the country's water supply, such as the clearing of invasive alien plant species.

\section{Impacts of invasive alien plants species on water resources}

A number of studies have been done to estimate the impacts of IAPs on water runoff (Wicht, 1943; Bosch and Hewlett, 1982; Scott and Smith, 1997; Kaiser, 1999; Baskin, 1999; Van Wilgen et al., 2001). These studies concurred that IAPs, inclusive of plantation forestry, have a measurable negative effect on streamflow. Versfeld et al. (1998) indicated that all of South Africa is potentially subject to alien plant species invasion, but that it is the invasion of riparian zones and mountain catchment areas that are the most important from a streamflow reduction perspective.

\begin{tabular}{|c|c|c|c|c|c|c|c|}
\hline & Reco & pact of kr & $\begin{array}{c}\text { TABLE } 1 \\
\text { invasive alien p }\end{array}$ & t species on & ater ru & of & \\
\hline (A) Long-term reductio & ons in & measured $\mathrm{i}$ & erimental catchm & ts after commer & al fore & atic & \\
\hline Catchment (Site) & & Area (ha) & Mean annual & infall (mm/a) & Mean & Innt & $\begin{array}{l}\text { al reduction in runoff } \\
(\mathrm{mm} / \mathrm{a})\end{array}$ \\
\hline Cathedral Peak (KZN) & & $60-190$ & & & & & $\left(2600 \mathrm{~m}^{3} / \mathrm{ha} \cdot \mathrm{a}\right.$ \\
\hline Jonkershoek (Western Cap & & $30-250$ & 1300 & 2300 & 130 & 300 & $1300-3000 \mathrm{~m}^{3} / \mathrm{ha} \cdot \mathrm{a}$ \\
\hline Westfalia (Limpopo) & & $30-60$ & & & & & $\left(2000 \mathrm{~m}^{3} / \mathrm{ha} \cdot \mathrm{a}\right)$ \\
\hline Mokobulaan (Mpumalanga & & 25 & & & & & $\left(3400 \mathrm{~m}^{3} / \mathrm{ha} \cdot \mathrm{a}\right)$ \\
\hline Witklip (Mpumalanga) & & $110-160$ & & & & & $\left(2800 \mathrm{~m}^{3} / \mathrm{ha} \cdot \mathrm{a}\right)$ \\
\hline (B) Riparian clearing e & experi & & & & & & \\
\hline Catchment (site) & & & Vegetation & & $\begin{array}{r}\text { Shor } \\
\text { inc }\end{array}$ & $\underline{s}$ & $\begin{array}{l}\text { average streamflow } \\
\left(\mathrm{m}^{3} / \mathrm{cleared} \mathrm{ha} \cdot \mathrm{d}\right)\end{array}$ \\
\hline Zwartkops (Eastern Cape) & & & Wattle & & & & 13 \\
\hline Lydenburg (Mpumalanga) & & & Pines \& Wattle & & & & 12 \\
\hline Witklip (Mpumalanga) & & & Pines \& Scrub & & & & 22 \\
\hline Du Toitskloof (Western Ca & ape) & & Wattle \& Eucalyptu & & & & 9 \\
\hline Oaklands (Western Cape) & & & Wattle \& Eucalyptu & & & & 10 \\
\hline Somerset West (Western C & Cape) & & Wattle \& Eucalyptu & & & & 12 \\
\hline Jonkershoek (Western Cap & & & Pines & & & & 31 \\
\hline Westfalia (Western Cape) & & & Indigenous forest & & & & 15 \\
\hline (C) Evapotranspiration & $\mathrm{n} \mathrm{mea}$ & nts & & & & & \\
\hline Catchment (site) & Vege & iparian) & & 2-month evapot & ispirat & on ( & $\mathrm{im)}$ \\
\hline & & & Transpiration & Interception & E1 & & Difference \\
\hline Jonkershoek (Western & Wattl & & 1318 & 171 & 148 & & $157\left(1570 \mathrm{~m}^{3} / \mathrm{ha} \mathrm{a}\right)$ \\
\hline Cape) & Fynbc & & & & 13 & & \\
\hline (KwaZulu- & Wattl & & 1077 & 183 & 126 & & $424\left(4240 \mathrm{~m}^{3} / \mathrm{ha} \cdot \mathrm{a}\right)$ \\
\hline Natal) & Grass & & & & 83 & & \\
\hline (D) Riparian vs. non-ri & iparia & tions in run & & & & & \\
\hline Catchment (site) & Trea & & & $\begin{array}{l}1^{\text {st }} \text { year incre } \\
\text { streamflow afte } \\
\text { ment ( } m^{3} / \text { ha cl }\end{array}$ & $\begin{array}{l}\text { in } \\
\text { reat- } \\
\text { red) }\end{array}$ & & $\begin{array}{l}\text { Ratio of riparian: } \\
\text { l-riparian increase }\end{array}$ \\
\hline Westfalia (Limpopo) & Clea & indigenous $\mathrm{f}$ & & 5445 & & & $2: 1$ \\
\hline & Clea & arian indigen & & 2700 & & & \\
\hline Witklip (Mpumalanga) & Clea & scrub \& pinc & & 7965 & & & $1.9: 1$ \\
\hline & Clea & arian pines & & 4045 & & & \\
\hline Biesiesvlei (Western & Clea & pines & & 11505 & & & $3.4: 1$ \\
\hline Cape) & Clea & arian pines & & 3430 & & & \\
\hline
\end{tabular}

Görgens and Van Wilgen (2004) 
The level of streamflow reduction is linked to the vegetation type and the density thereof. Research has shown that there is an inverse correlation between runoff (or streamflow) and plant biomass loads (Le Maitre et al., 1996; Versfeld et al., 1998), and the link between changes in runoff and the occurrence of invasive alien species has also been shown (Table 1).
The way in which streamflow reduction is influenced by the type and degree of infestation of IAPs, and whether the infestation occurs in mountain catchments or riparian zones, motivated Cullis et al. (2007) to estimate the overall reduction in water yield by IAPs per water management area (WMA). South Africa is divided into 19 Water Management Areas that correspond

\begin{tabular}{|l|c|c|c|c|c|c|c|c|}
\hline \multicolumn{9}{|c|}{ Reduction in mean annual runoff and yield due to non-riparian IAPs in mountain catchment areas by WMA } \\
\hline \multirow{3}{*}{ WMA } & Incremental MAR & Yield from minor dams & Yield from major dams & \multicolumn{2}{c|}{ RoR yield: disturbed } \\
\cline { 2 - 10 } & Current & Future & Current & Future & Current & Future & Current & Future \\
\cline { 2 - 10 } & $\mathbf{M m}^{3 / \mathbf{a}}$ & $\mathbf{M m}^{3 / \mathbf{a}}$ & $\mathbf{\mathbf { M m } ^ { 3 } / \mathbf { a }}$ & $\mathbf{M m}^{3 / \mathbf{a}}$ & $\mathbf{M m}^{3 / \mathbf{a}}$ & $\mathbf{M m}^{3 / \mathbf{a}}$ & $\mathbf{M m}^{3 / \mathbf{a}}$ & $\mathbf{M m}^{3 / \mathbf{a}}$ \\
\hline Berg & 19 & 96 & 0.3 & 1.6 & 3.5 & 12.1 & 9.5 & 43.6 \\
\hline Breede & 29 & 167 & 0.3 & 5.0 & 11.0 & 37.0 & 12.5 & 74.7 \\
\hline Crocodile (West) \& Marico & 0 & 0 & 0.0 & 0.0 & 0.0 & 0.0 & 0.0 & 0.0 \\
\hline Fish to Tsitsikama & 9 & 50 & 0.0 & 0.4 & 0.1 & 1.3 & 3.7 & 20.6 \\
\hline Gouritz & 16 & 53 & 0.0 & 0.2 & 0.3 & 1.4 & 6.1 & 20.3 \\
\hline Inkomati & 66 & 207 & 0.5 & 1.2 & 9.3 & 43.4 & 25.7 & 76.9 \\
\hline Limpopo & 1 & 6 & 0.0 & 0.0 & 0.1 & 1.4 & 0.0 & 0.5 \\
\hline Lower Orange & 0 & 0 & 0.0 & 0.0 & 0.0 & 0.0 & 0.0 & 0.0 \\
\hline Lower Vaal & 0 & 0 & 0.0 & 0.0 & 0.0 & 0.1 & 0.0 & 0.0 \\
\hline Luvuvhu and Letaba & 14 & 73 & 0.7 & 2.0 & 3.3 & 14.6 & 4.0 & 19.6 \\
\hline Middle Vaal & 0 & 0 & 0.0 & 0.0 & 0.0 & 0.0 & 0.0 & 0.0 \\
\hline Mvoti to Umzimkulu & 47 & 569 & 0.6 & 6.0 & 1.9 & 37.8 & 13.9 & 186.2 \\
\hline Mzimvubu to Keiskamma & 15 & 665 & 0.0 & 0.7 & 3.5 & 26.2 & 3.8 & 149.1 \\
\hline Olifants & 25 & 78 & 0.1 & 0.4 & 7.4 & 16.4 & 10.9 & 28.4 \\
\hline Olifants/Doorn & 2 & 13 & 0.0 & 0.2 & 0.3 & 3.0 & 0.7 & 4.7 \\
\hline Thukela & 20 & 416 & 0.4 & 4.3 & 3.8 & 76.2 & 5.6 & 115.0 \\
\hline Upper Orange & 0 & 15 & 0.0 & 0.0 & 0.0 & 95.3 & 0.0 & 4.5 \\
\hline Vaal & 1 & 19 & 0.0 & 0.0 & 0.7 & 7.3 & 0.1 & 2.2 \\
\hline Usutu to Mhlathuze & 55 & 459 & 0.3 & 1.5 & 14.4 & 137.4 & 12.5 & 129.4 \\
\hline TOTAL & 319 & 2887 & 3 & 24 & 60 & 511 & 109 & 875 \\
\hline
\end{tabular}

Source: Cullis et al. (2007).

Notes: $M A R=$ mean annual runoff and $R o R=$ run of river

\begin{tabular}{|c|c|c|c|c|c|c|}
\hline \multicolumn{7}{|c|}{$\begin{array}{c}\text { TABLE } 3 \\
\text { Reduction in yield due to IAPs in riparian zones by WMA }\end{array}$} \\
\hline \multirow[t]{3}{*}{ WMA } & \multirow[t]{2}{*}{$\begin{array}{l}\text { Total length of } \\
\text { rivers }\end{array}$} & \multirow[t]{2}{*}{$\begin{array}{l}\text { Riparian area } \\
\text { for perennial } \\
\text { rivers }\end{array}$} & \multicolumn{2}{|c|}{$\begin{array}{l}\text { Condensed invaded riparian area } \\
\text { for perennial and non-perennial } \\
\text { rivers }\end{array}$} & \multicolumn{2}{|c|}{$\begin{array}{l}\text { Reduction in yield due to IAPs } \\
\text { in perennial and non-perennial } \\
\text { riparian areas }\end{array}$} \\
\hline & & & Current & Future & Current & Future \\
\hline & $(\mathbf{k m})$ & $\left(\mathrm{km}^{2}\right)$ & $\left(\mathbf{k m}^{2}\right)$ & $\left(\mathrm{km}^{2}\right)$ & $\left(\mathrm{Mm}^{3}\right)$ & $\left(\mathrm{Mm}^{3}\right)$ \\
\hline Berg & 1884 & 245 & 45 & 78 & 5 & 9 \\
\hline Breede & 3179 & 677 & 83 & 144 & 11 & 20 \\
\hline Crocodile (West) \& Marico & 5027 & 228 & 81 & 281 & 15 & 51 \\
\hline Fish to Tsitsikamma & 15806 & 340 & 412 & 717 & 57 & 100 \\
\hline Gouritz & 8284 & 214 & 114 & 392 & 17 & 58 \\
\hline Inkomati & 3908 & 208 & 67 & 232 & 13 & 45 \\
\hline Limpopo & 5424 & 283 & 93 & 320 & 18 & 61 \\
\hline Lower Orange & 23704 & 240 & 66 & 755 & 8 & 88 \\
\hline Lower Vaal & 6562 & 100 & 24 & 279 & 3 & 34 \\
\hline Luvuvhu and Letaba & 2787 & 142 & 14 & 163 & 3 & 31 \\
\hline Middle Vaal & 5874 & 243 & 183 & 318 & 32 & 56 \\
\hline Mvoti to Umzimkulu & 11935 & 958 & 491 & 853 & 109 & 190 \\
\hline Mzimvubu to Keiskamma & 5419 & 353 & 202 & 351 & 42 & 73 \\
\hline Olifants & 6915 & 418 & 249 & 433 & 50 & 87 \\
\hline Olifants/Doorn & 7869 & 163 & 27 & 306 & 4 & 44 \\
\hline Thukela & 4378 & 327 & 174 & 302 & 38 & 65 \\
\hline Upper Orange & 11574 & 360 & 50 & 571 & 8 & 90 \\
\hline Upper Vaal & 7835 & 549 & 152 & 524 & 32 & 111 \\
\hline Usutu to Mhlatuze & 7132 & 507 & 277 & 481 & 59 & 103 \\
\hline Total & 145494 & 5726 & 2804 & 7501 & 523 & 1314 \\
\hline
\end{tabular}

Source: Cullis et al. (2007) 


\begin{tabular}{|c|c|c|c|c|}
\hline \multicolumn{5}{|c|}{$\begin{array}{c}\text { TABLE } 4 \\
\text { Total reduction in yield due to IAPs (mountain catchment areas plus riparian areas) by } \\
\text { WMA }\end{array}$} \\
\hline \multirow[t]{2}{*}{ WMA } & \multicolumn{2}{|c|}{ Current levels of infestation } & \multicolumn{2}{|c|}{ Future levels of infestation } \\
\hline & $\mathrm{Mm}^{3}$ & $\begin{array}{l}\% \text { of registered } \\
\text { water use }\end{array}$ & $\mathrm{Mm}^{3}$ & $\begin{array}{l}\% \text { of registered } \\
\text { water use }\end{array}$ \\
\hline Berg & 19 & 2.6 & 66 & 9.2 \\
\hline Breede & 35 & 5.3 & 136 & 20.7 \\
\hline Crocodile (West) and Marico & 15 & 1.7 & 51 & 5.8 \\
\hline Fish to Tsitsikamma & 61 & 4.4 & 121 & 8.7 \\
\hline Gouritz & 23 & 5.8 & 79 & 20.1 \\
\hline Inkomati & 49 & 3.7 & 166 & 12.5 \\
\hline Limpopo & 18 & 2.9 & 63 & 10.1 \\
\hline Lower Orange & 8 & 0.7 & 88 & 7.8 \\
\hline Lower Vaal & 3 & 0.4 & 34 & 4.2 \\
\hline Luvuvhu and Letaba & 11 & 2.1 & 67 & 13.2 \\
\hline Middle Vaal & 32 & 5.3 & 56 & 9.2 \\
\hline Mvoti to Umzimkulu & 126 & 14.8 & 420 & 49.3 \\
\hline Mzimvubu to Keiskamma & 49 & 5.6 & 249 & 28.4 \\
\hline Olifants & 69 & 6.8 & 133 & 13.1 \\
\hline Olifants-Doorn & 5 & 1.5 & 52 & 16.1 \\
\hline Thukela & 48 & 12.1 & 261 & 66.6 \\
\hline Upper Orange & 8 & 0.5 & 190 & 13.1 \\
\hline Upper Vaal & 33 & 1.8 & 121 & 6.6 \\
\hline Usutu to Mhlatuze & 86 & 7.6 & 371 & 32.7 \\
\hline South Africa & 695 & 4.1 & 2724 & 16.1 \\
\hline
\end{tabular}

Source: Cullis et al. (2007)

more or less to the major river basin areas. These estimates are provided in Table 2, (mountain catchment areas), Table 3 (riparian zones) and Table 4 (the total).

These estimates indicate that South Africa is currently losing utilisable water equal to $4.1 \%$ of the registered water use of the country (Table 4) due to the reduction in water yield from riparian and mountain catchment areas. If not controlled this could go up to as much as $16.1 \%$. The remainder of the paper will focus on determining a structure and level of a charge that would be sufficient, appropriate, practical, and that could be levied on water users to combat IAPs.

\section{Calculation of the user charge for the control of IAPs}

\section{Background}

Given the impact of IAPs on streamflow, the government decided in 1995 to commission a public programme Working for Water (WfW) under the jurisdiction of the Department of Water Affairs and Forestry (DWAF) to control the infestation of alien plant species. The WfW Programme has an annual budget of approximately $\mathrm{R} 450 \mathrm{~m}$. and employs more than 33000 previously unemployed individuals (RSA, 2003), which constitutes the largest single poverty relief and public works expenditure in the country. The Programme effectively acts as conduit for the provision of environmental goods and services, most notably water supply, through the removal of IAPs, and the provision of unskilled job opportunities, using taxpayers' money. Though the WfW has many benefits, can it be improved? Currently payments made, either to WfW or to the contractor who is directly involved in the removal of IAPs, are not strongly linked to water supply delivery targets. Payments are linked to hectares cleared and the result- ant job creation in the process is more often than not seen as the major project delivery. This would make sense from the perspective of a public works programme, but it might not be an optimal allocation of resources since the financial investment is not linked to water provision - which is one of its major objectives. Also, while the programme is involved in removing IAPs, it creates the impression that neither the landowner nor the water user is responsible for the presence of weeds either on their land or in the catchment from where they derive their water.

To remove the inherent problems associated with WfW a much bigger system is required, a system that includes all water users. Legislation (DWAF, 2005) allows for the introduction of an invasive alien plant water charge:

'The cost of controlling invasive alien plants with acknowledged negative impacts on water resources; e.g. riparian zones, mountain catchment areas, wetlands and in areas where there could be an impact on aquifers may be charged to affected water users.... in consultation with affected stakeholders, will recommend whether the control of IAPs in a particular catchment is necessary for water security,.... before going ahead with clearing, the cost of control must be communicated to all affected stakeholder organisations. These costs will be supported by subsidy where available and appropriate. The agreed upon cost of control will then be allocated to all water user sectors in proportion to their registered abstraction related water use. In the event of consensus not been reached amongst water user sectors,.... will go ahead with clearing in cooperation with those sectors who have agreed to participate in the clearing process. The resultant additional water after taking the Ecological Reserve and reducing over-allocation into account may be allocated to sectors that financially participated in the clearing project.' 
The principles and operating mechanism for implementing a charge are clearly communicated by government. Water users should pay for their water, and in those water management areas where it is deemed necessary and appropriate, an IAP control charge could be levied. This charge will be added onto the existing water resource management charge. Should the charge be excessive, government could provide a subsidy to support the programme. Legislation does not determine either the level or the method in calculating this charge, but does state that the charge should be linked to their registered water use. The method and level of this charge will be determined here for three main water use categories namely bulk (domestic and industrial), agriculture and forestry.

\section{Method}

The most appropriate level of the charge for controlling IAPs was determined in five stages. These will subsequently be discussed.

\section{Stage 1: Calculation of an average clearing cost per water management area}

Based on historic WfW records it was possible to calculate what it would cost to clear each WMA of IAPs situated in mountain catchments and in riparian zones. This average cost was estimated after taking the different densities of the different species within each of the different WMAs into consideration and was calculated over three different clearing cycles, namely 15 , 20 and 25 years. Based on practical experience of the WfW programme we focus on 25 years here, since it seems to be the more realistic.

\section{Stage 2: Estimation of a series of three individual weighed tariffs: \\ The baseline tariff (T1)}

It is accepted that the sectors with the largest water use will be more sensitive to tariff increases. The cost of clearing estimated in Stage 1 was therefore weighted proportionately to the registered water use per sector.

\section{Incorporation of the assurance of supply (T2)}

To incorporate the assurance of supply, the cost of clearing estimated in Stage 1 was subsequently weighed with the degree of assurance of supply to estimate T2. Bulk water use has a very high ( $99 \%$ to $99.9 \%$ ) assurance of supply and was therefore set at 1 , while agriculture only has a $70 \%$ assurance of supply. It is therefore only fair that the higher the assurance the higher the tariff. There is, however, some difficulty in allocating the assurance of supply to the forestry sector. Some argue that as forestry is a streamflow reduction activity and therefore dependent on rainfall, their assurance of supply will be the lowest. Others, however, argue that forestry is generally upstream and therefore has access to all runoff before any other water user. This study did not attempt to develop an argument for the allocation of a fair assurance of supply value for forestry, and assumed that the forestry assurance of supply is somewhere between that of agriculture and bulk water supply and used a value of $90 \%$.

\section{Incorporation of the raw water charge (T3)}

To assure equitability and affordability across all the WMA's and water use sectors the raw water charge was used and the third tier of individually weighed tariffs using the cost of clearing estimated in Stage 1.

\section{Stage 3: Estimation of a non-equalised tariff (T4)}

During Stage 2, three different tariffs for each of the three water use sectors in each of the 19 WMAs were calculated based on the volume of water use, the assurance of supply and the current water tariff payable. The non-equalised tariff is the average of the above three tariffs allocated to each sector and for each WMA separately, i.e. $((\mathrm{T} 1+\mathrm{T} 2+\mathrm{T} 3) / 3)$.

\section{Stage 4: Estimation of a gross equalised tariff (T5)}

Multiplying T4 with the registered water use does not equate to the total cost of clearing per WMA (as per Stage 1). To calculate the charge for the control of IAPs it is necessary to estimate the total income if the non-equalised tariff (T4) used in conjunction with the registered water use per sector in each water management area. The gross equalised tariff is then estimated by adjusting the non-equalised tariff according to the ratio of estimated clearing costs to non-equalised income potential.

\section{Stage 5: Subsidised tariff (T6)}

The subsidy that each water use sector in each WMA may apply for was based on the users' ability to pay for invasive alien plant control. If the water resource management charge is smaller than the gross equalised tariff, then the difference between the two is considered as a subsidy. The current proposal is to fund the subsidies from the Government's existing expanded public works programme (EPWP). It fits well with the objectives of the EPWP in that it will secure and release water resources for economic use. The intervention can be equated to the restoration and maintenance of infrastructure. It can therefore be described as the maintenance and restoration of 'natural water infrastructure'.

\section{Results}

Table 5 reflects the estimated invasive alien plant control charge per water management area and major water user group using the method discussed above. The EPWP component is the subsidy (T6), whereas the EPWP component and the sector component combined is the total charge (T5). Given the registered water use per water use sector and WMA, the total value of the charge to the respective sectors and the subsidy per water management area is provided in Table 6. The distribution of the burden of the charge among the water use sectors is also indicated.

\section{Discussion}

Though the method discussed above is rigorous and done in as much detail as possible and taking as many as possible variables into consideration, there are still some shortcomings. Firstly the shortcomings of the models developed by Cullis et al. (2007) need to be taken into account. The study included only those quaternary catchments with a mean annual precipitation (MAP) of more than $800 \mathrm{~mm}$. A substantial percentage of the original mountain catchments listed in the Department of Agricultural Technical Services Report (1961) occur in dry areas where the average MAP for the total catchment is below $800 \mathrm{~mm}$. The MAP in the mountain (watershed), however, is much higher. This means that the runoff from those mountains contributes to the bulk of the runoff in the catchment, but for the purposes of this study they are not included as contributing to the utilisable runoff. They are therefore not recognised as mountain catchment areas.

The estimates here were made at a WMA-level, which is not necessarily practical for water resource managers. However, 


\begin{tabular}{|l|l|c|c|c|c|c|c|}
\hline \multicolumn{7}{|c|}{ Invasive alien control charge over a 25-year clearing cycle (c/m $\mathbf{m}^{3}$} \\
\hline No. & Name & $\begin{array}{c}\text { Domestic \& } \\
\text { industrial }\end{array}$ & $\begin{array}{c}\text { EPWP } \\
\text { D\&I }\end{array}$ & Agric. & $\begin{array}{c}\text { EPWP } \\
\text { agric. }\end{array}$ & Forestry & $\begin{array}{c}\text { EPWP } \\
\text { forestry }\end{array}$ \\
\hline 1 & Limpopo & 0.50 & 0 & 0.53 & 0 & 0.19 & 0 \\
\hline 2 & Luvuvhu and Letaba & 1.69 & 0 & 1.26 & 0.39 & 0.37 & 0.33 \\
\hline 3 & Crocodile (West) and Marico & 0.33 & 0 & 0.26 & 0 & 0.10 & 0 \\
\hline 4 & Olifants & 1.71 & 1.46 & 0.80 & 1.13 & 0.25 & 0.54 \\
\hline 5 & Inkomati & 1.33 & 3.33 & 0.64 & 2.74 & 0.31 & 1.85 \\
\hline 6 & Usutu to Mhlatuze & 0.81 & 8.26 & 0.40 & 4.67 & 0.24 & 3.74 \\
\hline 7 & Thukela & 0.57 & 6.45 & 0.36 & 4.02 & 0.14 & 2.05 \\
\hline 8 & Upper Vaal & 0.07 & 0 & 0.02 & 0 & 0.01 & 0 \\
\hline 9 & Middle Vaal & 0.15 & 0 & 0.09 & 0 & 0.05 & 0 \\
\hline 10 & Lower Vaal & 0.20 & 0 & 0.17 & 0 & 0.05 & 0 \\
\hline 11 & Mvoti to Umzimkulu & 1.46 & 8.26 & 0.54 & 3.17 & 0.45 & 3.54 \\
\hline 12 & Mzimvubu to Keiskamma & 2.05 & 1.40 & 0.62 & 0.89 & 0.26 & 0.67 \\
\hline 13 & Upper Orange & 0.10 & 0 & 0.10 & 0 & 0.04 & 0 \\
\hline 14 & Lower Orange & 0.15 & 0 & 0.18 & 0 & 0.07 & 0 \\
\hline 15 & Fish to Tsitsikamma & 1.31 & 0 & 0.70 & 0.50 & 0.13 & 0.29 \\
\hline 16 & Gouritz & 2.61 & 2.48 & 0.72 & 3.65 & 0.14 & 1.40 \\
\hline 17 & Olifants / Doorn & 0.33 & 0 & 0.39 & 0 & 0.14 & 0 \\
\hline 18 & Breede & 1.57 & 0 & 0.64 & 0.98 & 0.09 & 0.48 \\
\hline 19 & Berg & 1.10 & 0 & 0.48 & 0.07 & 0.20 & 0.12 \\
\hline & & 0.95 & 4.52 & 0.47 & 2.02 & 0.17 & 1.36 \\
\hline
\end{tabular}

$E P W P=$ Extended public works programme, i.e. the government subsidy

the model is developed in such a way that it could potentially be applied at smaller units, such as at the secondary catchment scale. However, when considering applying the model at a smaller scale one has to take into account the transaction costs for the implementation of the system.

Lastly, some of the cost estimates are high, such as for the Inkomati and Usutu to Mhlatuze WMAs. From an implementation perspective it will be highly impractical to spend $\mathrm{R} 44.5 \mathrm{~m}$./a and $\mathrm{R} 63 \mathrm{~m}$./a respectively in those two WMAs. It is suggested that this outcome can be ascribed to the quality of the original data from Versfeld et al. (1998) that is used by Cullis et al. (2007). At the other extreme it is suggested that the estimated cost of control (R1.26 m./a) in the Olifants/Doorn WMA is an underestimate. The reason for this can be ascribed to the fact that some of the mountain catchment areas in this water management area have been excluded as discussed under the first point above.

\section{Conclusion}

Natural capital is increasingly becoming the factor of limiting supply when considering economic development. Water in South Africa is no exception. Engineering-based water supply options are running out, but an alternative water augmentation system that operates within the ambit of the water pricing and extended public works programme framework is offering alternative options. Currently IAPs in mountain catchments (watersheds) consume more than $4 \%$ of all registered water use; if left uncontrolled this figure might become as high as $16 \%$. By adding an IAPs control charge to the water resource management charge of the water tariff it is possible to increase both the speed and the efficiency of the control of IAPs. The IAPs control charge developed here incorporates the volume of water use, the assurance of supply, the water tariff, equity, affordability, species- and site-specific characteristics. This charge is an application of the principles of the water pricing strategy of South Africa, which is in accordance with the philosophy of the establishment of either markets and/or payments for ecosystem goods and services and has the potential to improve water supply by between $4 \%$ and $16 \%$.

\section{References}

ARONSON J, BLIGNAUT J, MILTON SJ and CLEWELL A (2006) Natural capital: The limiting factor. Ecol. Eng. 281-5.

ASHTON PJ (2002) Avoiding conflicts over Africa's water resources. Ambio 31 (3) 236-242.

BASKIN Y (1999) Curbing undesirable invaders. BioSci. 46 (10) 732-7. BOSCH JM and HEWLETT JD (1982) A review of catchment experiments to determine the effect of vegetation changes on water yield an evapotranspiration. J. Hydrol. 55 (3) 3-23.

CULLIS J, GÖRGENS A and MARAIS C (2007) A strategic study of the impact of invasive alien vegetation in the mountain catchment areas and riparian zones of South Africa on total surface water yield. Water $S A 33$ (1) 35-42.

DEPARTMENT OF AGRICULTURAL TECHNICAL SERVICES (1961) Report of the Interdepartmental Committee on the Conservation of Mountain Catchments in South Africa ('The Ross Report'). Pretoria: DoA.

DWAF (DEPARTMENT OF WATER AFFAIRS AND FORESTRY) (1998) National Water Act for South Africa. Pretoria: DWAF.

DWAF (Department of Water Affairs and Forestry) (2002) National Water Resource Strategy. Pretoria: DWAF.

DWAF (Department of Water Affairs and Forestry) (2004) National Water Resource Strategy: First edition, September. Pretoria: DWAF.

DWAF (Department of Water Affairs and Forestry) (2005) Establishment of a Pricing Strategy for Water Use Charges in Terms of Section 56(1) of the National Water Act, 1998. Pretoria: DWAF. 


\begin{tabular}{|c|c|c|c|c|c|c|}
\hline \multicolumn{7}{|c|}{$\begin{array}{c}\text { TABLE } 6 \\
\text { Water charges, and subsidies needed, for the control of IAPs in the mountain catchment areas and riparian } \\
\text { zones of South Africa over a } 25 \text {-year clearing cycle }\end{array}$} \\
\hline $\begin{array}{l}\text { WMA } \\
\text { No. }\end{array}$ & Name & $\begin{array}{c}\text { EPWP } \\
\text { (Subsidy) }\end{array}$ & $\begin{array}{l}\text { Industrial \& } \\
\text { domestic use }\end{array}$ & $\begin{array}{l}\text { Agricultural } \\
\text { use }\end{array}$ & Forestry & Total \\
\hline \multirow[t]{2}{*}{1} & Limpopo & R 0 & R 245214 & R 3058576 & $\mathrm{R} 448$ & R 3304237 \\
\hline & $\%$ & - & 7 & 93 & 0 & 100 \\
\hline \multirow[t]{2}{*}{2} & Luvuvhu and Letaba & R 1814042 & R 659567 & R 5433230 & R 134376 & R 8041216 \\
\hline & $\%$ & 23 & 8 & 68 & 2 & 100 \\
\hline \multirow[t]{2}{*}{3} & Crocodile (West) and Marico & R 0 & R 685105 & R 1738797 & R 259 & R 2424161 \\
\hline & $\%$ & - & 28 & 72 & 0 & 100 \\
\hline \multirow[t]{2}{*}{4} & Olifants & R 12166520 & R 4772768 & R 5612928 & R 78073 & R 22630289 \\
\hline & $\%$ & 54 & 21 & 25 & 0 & 100 \\
\hline \multirow[t]{2}{*}{5} & Inkomati & R 35437005 & R 3066517 & R 5398835 & R 783222 & R 44685579 \\
\hline & $\%$ & 79 & 7 & 12 & 2 & 100 \\
\hline \multirow[t]{2}{*}{6} & Usutu to Mhlatuze & R 58287441 & R 1852403 & R 2391434 & R 747519 & R 63278797 \\
\hline & $\%$ & 92 & 3 & 4 & 1 & 100 \\
\hline \multirow[t]{2}{*}{7} & Thukela & R 18082175 & R 676894 & R 880421 & R 38167 & R 19677657 \\
\hline & $\%$ & 92 & 3 & 4 & 0 & 100 \\
\hline \multirow[t]{2}{*}{8} & Upper Vaal & R 0 & R 1017942 & R 67629 & $\mathrm{R} 1$ & R 1085572 \\
\hline & $\%$ & - & 94 & 6 & 0 & 100 \\
\hline \multirow[t]{2}{*}{9} & Middle Vaal & $\mathrm{R} 0$ & R 462583 & R 271580 & R 0 & R 734163 \\
\hline & $\%$ & - & 63 & 37 & - & 100 \\
\hline \multirow[t]{2}{*}{10} & Lower Vaal & R 0 & R 139653 & R 1845031 & R 0 & R 1984684 \\
\hline & $\%$ & - & 7 & 93 & - & 100 \\
\hline \multirow[t]{2}{*}{11} & Mvoti to Umzimkulu & R 50753163 & R 6634240 & R 1130940 & R 845011 & R 59363355 \\
\hline & $\%$ & 85 & 11 & 2 & 1 & 100 \\
\hline \multirow[t]{2}{*}{12} & Mzimvubu to Keiskamma & R 10205575 & R 10032292 & R 2204108 & R 82207 & R 22524182 \\
\hline & $\%$ & 45 & 45 & 10 & 0 & 100 \\
\hline \multirow[t]{2}{*}{13} & Upper Orange & R 0 & R 204451 & R 1296651 & R 0 & R 1501103 \\
\hline & $\%$ & - & 14 & 86 & - & 100 \\
\hline \multirow[t]{2}{*}{14} & Lower Orange & R 0 & R 104178 & R 1880507 & R 0 & R 1984684 \\
\hline & $\%$ & - & 5 & 95 & - & 100 \\
\hline \multirow[t]{2}{*}{15} & Fish to Tsitsikamma & R 6065698 & R 2046429 & R 8435859 & R 20587 & R 16568573 \\
\hline & $\%$ & 37 & 12 & 51 & 0 & 100 \\
\hline \multirow[t]{2}{*}{16} & Gouritz & R 13772967 & R 907608 & R 2526138 & R 16955 & R 17223668 \\
\hline & $\%$ & 80 & 5 & 15 & 0 & 100 \\
\hline \multirow[t]{2}{*}{17} & Olifants / Doorn & R 0 & R 27612 & R 1233194 & R 159 & R 1260965 \\
\hline & $\%$ & - & 2 & 98 & 0 & 100 \\
\hline \multirow[t]{2}{*}{18} & Breede & R 6003407 & R 675739 & R 3932127 & R 4637 & R 10615910 \\
\hline & $\%$ & 57 & 6 & 37 & 0 & 100 \\
\hline \multirow[t]{5}{*}{19} & Berg & R 208872 & R 4658665 & R 1406574 & R 953 & R 6275065 \\
\hline & $\%$ & 3 & 74 & 22 & 0 & 100 \\
\hline & Total & R 212796866 & R 38869860 & R 50744560 & R 2752575 & R 305163861 \\
\hline & Average $\%$ & 34 & 22 & 44 & $\mathbf{0}$ & 100 \\
\hline & $\begin{array}{l}\text { Estimated total water user } \\
\text { charges }\end{array}$ & & & & R 92366995 & \\
\hline
\end{tabular}


GÖRGENS A and VAN WILGEN BW (2004) Invasive alien plants and water resources in South Africa: current understanding, predictive ability and research challenges. S. Afr. J. Sci. 100 (1) 27-33.

KAISER J (1999) Stemming the tide of invasive species. Sci. 285 (5435) 1836-1841.

LE MAITRE D, VAN WILGEN BW, CHAPMAN RA and MCKELLY DH (1996) Invasive plants in the Western Cape, South Africa: modelling the consequences of a lack of management. J. Appl. Ecol. 33 161-172.

PAGIOLA S, BISHOP J and LANDELL-MILLS N (2002) Selling Forest Environmental Services. Earthscan, London.

RSA (REPUBLIC OF SOUTH AFRICA) (2003) Estimates of National Expenditures. Pretoria: National Treasury.

SCHOLES R (2001) Global Terrestrial Observing System: Regional Implementation Plan for Southern Africa. GTOS-21. CSIR, Pretoria.

SCHREINER B and VAN KOPPEN B (2002) Catchment management agencies for poverty eradication in South Africa. Phys. \& Chem. Earth 27 969-976.
SCOTT D and SMITH R (1997) Preliminary empirical models to predict reductions in total and low flows resulting from afforestation. Water SA 23 (2) 187-200.

SMAKHTIN V, ASHTON PJ, BATCHELOR A, MEYER R, MAREE JP, MURRAY M, BARTA B, BAUER N, TERBLANCHE D and OLIVIER J (2001) Unconventional water supply options in South Africa: possible solutions or intractable problems? Water Int. 26 (3) 314-34.

VAN WILGEN BW, RICHARDSON DM, LE MAITRE DC, MARAIS $C$ and MAGADLELA D (2001) The economic consequences of alien plant invasions: Examples of impacts and approaches to sustainable management in South Africa. Env. Dev. \& Sust. 3 145-168.

VERSFELD DB, LE MAITRE DC and CHAPMAN RA (1998) Alien Invading Plants and Water Resources in South Africa: A Preliminary Assessment. CSIR Report, Stellenbosch: CSIR Division of Water, Environment and Forestry Technology.

WICHT CL (1943) Determination of the effects of watershed management on mountain streams. Trans. Am. Geophys. Union 2 594-608. 